\title{
A Brief Description of the 18th Century Scientific Instruments recently discovered at Longleat, the home of the Marquess of Bath.
}

\author{
By Dr. H. Heywood
}

ABSTRACT of Paper read on 23rd February, 1953

The Author has had the privilege of assisting the present Lord Bath in cataloguing and assembling a number of historic scientific instruments recently discovered in various boxes and cupboards in the Old Library at Longleat, near Warminster. The present building at Longleat was commenced in 1567 by Sir John Thynne; the first Viscount Weymouth was created by Charles II, and the first Marquess of Bath by George III. Bishop Ken of Bath and Wells, one of the dissenting bishops, was a lifelong friend of the first Viscount Weymouth, and lived at Longleat in the Old Library for many years. It is possible that some of the earlier instruments may have belonged to Bishop Ken or have been purchased at his suggestion. .

The earliest group of instruments date from the period 1690 to 1710 , and are as follows :-

A Marshall Microscope, complete except for eyepiece lens, and possibly one of the earliest examples of this maker.

The casing of a vellum telescope with red and green blotched surface and gold stamps.

An air pump presumably by Hawksbee, in perfect working order and exactly similar to that in the possession of the Royal Society of London.

A Davis backstaff but with maker's nameplate missing, and part of a crosis staff.

The second group of instruments dates from the period 1720 to 1750 :-

A very fine cabinet of drawing instruments by Thomas Heath.

A universal sundial by Thomas Heath, very beautifully engraved.

A wheel milometer or Waywiser by Thomas Wright.

A small Gregorian telescope, no maker's name.

A thermometer and barometer by John Carutty of Bath.

The final group of instruments covers the period 1795 to 1820 approximately :-

A George Adams Universal Microscope, complete with all accessories and in perfect condition.

A maximum and minimum thermometer by George Adams.

A 5-inch aperture Gregorian telescope signed Adams, with letter of instructions written by Dudley Adams and dated 1811.

A corn balance by Fraser.

Terrestrial and Celestial Globes by Cary.

This collection of instruments has been assembled in the Bishop Ken Library, which is not generally opened to the public, but Miss Dorothy Coates, the Librarian, to whom the Author is greatly indebted, has kindly agreed to show them to visitors who are especially interested. A detailed description of the instruments is in preparation by the writer, and it is hoped to publish this shortly. 